\title{
Antibacterial Activity and Metabolomics Profiling of Torch Ginger (Etlingera elatior Jack) Flower Oil Extracted Using Subcritical Carbon Dioxide $\left(\mathrm{CO}_{2}\right)$
}

\author{
Aliaa Anzian, ${ }^{1}$ Belal J. Muhialdin,,3 ${ }^{2,3}$ ameer Khairullah Mohammed, ${ }^{4}$ Hana Kadum, ${ }^{5}$ \\ Anis Asyila Marzlan, ${ }^{1}$ Rashidah Sukor, ${ }^{2,6}$ and Anis Shobirin Meor Hussin $\mathbb{D}^{1,3}$ \\ ${ }^{1}$ Department of Food Technology, Faculty of Food Science and Technology, Universiti Putra Malaysia, 43400 Serdang, \\ Seri Kembangan, Selangor, Malaysia \\ ${ }^{2}$ Department of Food Science, Faculty of Food Science and Technology, Universiti Putra Malaysia, 43400 Serdang, \\ Seri Kembangan, Selangor, Malaysia \\ ${ }^{3}$ Halal Products Research Institute, Universiti Putra Malaysia, 43400 Serdang, Seri Kembangan, Selangor, Malaysia \\ ${ }^{4}$ Department of Food Science, Faculty of Agriculture, Tikrit University, Tikrit 34001, Iraq \\ ${ }^{5}$ Faculty of Science, University Muthanna, Samawah, Iraq \\ ${ }^{6}$ Institute of Tropical Agriculture and Food Security, Universiti Putra Malaysia, 43400 Serdang, Seri Kembangan, \\ Selangor, Malaysia \\ Correspondence should be addressed to Anis Shobirin Meor Hussin; anisshobirin@gmail.com
}

Received 28 December 2019; Revised 23 March 2020; Accepted 16 April 2020; Published 14 May 2020

Academic Editor: Letizia Angiolella

Copyright (C) 2020 Aliaa Anzian et al. This is an open access article distributed under the Creative Commons Attribution License, which permits unrestricted use, distribution, and reproduction in any medium, provided the original work is properly cited.

\begin{abstract}
The aim of this study was to identify the bioactive compound and evaluate the antibacterial activity of torch ginger flower oil extracted using subcritical carbon dioxide. The antibacterial activity was evaluated in agar diffusion assay, while MIC and MBC were determined using the microdilution broth assay. The essential oil was subjected to metabolomics profiling using GC-MS and ${ }^{1} \mathrm{H}-\mathrm{NMR}$ techniques. The results demonstrated strong antibacterial activity towards Salmonella typhimurium, Staphylococcus aureus, and Escherichia coli. The MIC values were $0.0625,0.25$, and $0.25 \mathrm{mg} / \mathrm{mL}$, and the MBC values were $0.25,0.5$, and $1 \mathrm{mg} / \mathrm{mL}$ towards $S$. typhimurium, S. aureus, and E. coli, respectively. A total of 33 compounds were identified using GC-MS including 15 compounds (45\%) known for their antimicrobial activity. In addition, sixteen metabolites were identified using NMR analysis and 8 out of the sixteen metabolites $(50 \%)$ have antibacterial activity. The extracted oil demonstrated broad range for antibacterial activity and has high potential for applications in pharmaceutical and food industries. Practical Applications. The oil extracted from the torch ginger flower was found very stable and has promising applications as antibacterial agent for food and pharmaceutical industries.
\end{abstract}

\section{Introduction}

Oils extracted from the parts of aromatic plant such as barks, flowers, fruits, leaves, and rhizomes are economically important due to their applications in foods and pharmaceuticals [1]. The increasing demand for natural bioactive ingredients with biological functions including antioxidant and antibacterial activity has led the researchers to evaluate several promising plants extracts. Torch ginger (Etlingera elatior Jack) is an edible aromatic plant rich in phytochemicals and has well-known pharmacological properties
[2]. Several previous studies reported the antimicrobial activity of the torch ginger flower oil that was extracted using several organic solvents including acetone, ethanol, methanol, and hexane [3]. However, the antimicrobial activity of the oil extracted from torch ginger flower was reported to be declined after solvent extraction due to oxidative degradation during solvent removal which requires high temperatures [4]. On the other hand, the subcritical carbon dioxide $\left(\mathrm{CO}_{2}\right)$ extraction method can preserve the bioactive compound presence in the oil [5]. The $\mathrm{CO}_{2}$ extraction technique is friendly to environment, requires very low temperatures, 
and has low effects on the bioactive compounds including volatile compounds [6]. Previous studies demonstrated the advantages of $\mathrm{CO}_{2}$ extraction in comparison to solvent extraction for ajwain (Carum copticum) oil [7] and cardamom (Elettaria cardamomum Maton) oil [8].

The oil of torch ginger flower has been reported in many studies to have antimicrobial activity towards several pathogenic bacteria and identified the chemical compositions including some significant bioactive compounds with antimicrobial activity such as 1-dodecanol [9]. In the previous study, Susanti et al. [10] analysed the chemical compositions of the oil extracted from torch ginger flower obtained from Malaysia and identified 22 compounds including hydrocarbons, aldehydes, alcohols, ketones, esters, and acids. In a recent study, the oil extracted from the rhizome demonstrated strong antibacterial activity against 13 pathogenic bacteria and yeast including MRSA, and the bioactive compounds were identified by GC-MS as linalool formate and eugenol [11]. The oil has promising applications in foods as natural preservatives to replace and reduce the use of synthetic preservatives [12]. On the other hand, torch ginger flower oil has high potential for pharmaceutical applications as natural antibacterial agent. In the previous study, the oil extracted from different herbs was observed to reduce the microbial load and extend the shelf life of Asian sea bass fish for 33 days at 0 to $2^{\circ}$ [13]. However, the biodegradation of the bioactive phytochemicals and the loss of antibacterial activity after long storage are the main challenge for using oils in food applications. The stability of the phytochemicals and the antimicrobials activity are affected by the extraction methods and storage conditions [14]. In previous studies, oil of torch ginger flower was mainly extracted using organic solvents and no study determined the stability of the oil during prolonged storage [15]. To the best of our knowledge, there are no studies that determined the antibacterial activity of oil extracted from torch ginger flower using subcritical carbon dioxide $\left(\mathrm{CO}_{2}\right)$ extraction. Therefore, the aim of this study was to determine the effects of the $\mathrm{CO}_{2}$ extraction technique on the antibacterial activity of the oil of torch ginger flower and carry out the metabolic profiling using GC-MS and ${ }^{1} \mathrm{H}-\mathrm{NMR}$ based techniques. Moreover, the effects of storage for 12 months at $8^{\circ} \mathrm{C}$ on the antimicrobial activity were evaluated to determine the oil stability.

\section{Materials and Methods}

2.1. Chemicals and Reagents. Ethanol and hexane were purchased from R\&M Chemicals (Essex, UK). Mueller-Hinton Agar (MHA), Muller-Hinton broth (MHB), and nutrient agar (NA) were obtained from (Oxoid, Basingstoke, Hampire, England), (Difco, Becton Dickinson, France) and (Merck, Darmstadt, Germany), respectively. Streptomycin was purchased from Oxoid (Hampshire, England).

2.2. Plant Source and Preparation. The fresh torch ginger flowers $(50 \mathrm{~kg})$ were purchased from local supplier at Pasar Borong, Selangor. Voucher specimens of torch ginger flowers were identified by a botanist, Dr. Mohd Firdaus
Ismail, and deposited at the Phytomedicine Herbarium, Institute of Bioscience, Universiti Putra Malaysia, Selangor, Malaysia, under the voucher number SK 3176/17. The torch ginger flowers were separated from their stalks and stems and washed thoroughly under running water to remove dirt, and their surfaces were cleaned cautiously to remove adhering debris. The excess water was drained, and torch ginger flowers were cut into small pieces using a continuous slicer (thickness: $2 \mathrm{~mm}$ ). Torch ginger flowers were subjected to oven drying for $16 \mathrm{~h}$ in a at $40^{\circ} \mathrm{C}$ until their moisture content reached $10 \pm 2 \%$ using drying oven (Smoke Master Model SMA-112, Tokyo, Japan). The dried torch ginger flowers were grounded using a commercial blender (Blender 8010S, Model HGBTWTS3, Waring Commercial Torrington, USA) and then sieved through a $500 \mu \mathrm{m}$ mesh size and kept at room temperature for further analyses.

2.3. Subcritical Carbon Dioxide Extraction. The subcritical carbon dioxide $\left(\mathrm{CO}_{2}\right)$ extraction was carried out following the method described by Taraj, [16], with modification. The processed torch ginger flowers were soaked in solvent and drained automatically for several times. Carbon dioxide was continuously regenerated by a single stage or flash evaporation in the reboiler. A semicontinuous flow $\mathrm{SC}-\mathrm{CO}_{2}$ extraction system was used in the experiment (FeyeCon Development, Weesp, Netherlands). The extraction conditions were optimized for the temperature $28^{\circ} \mathrm{C}$, the pressure $7 \mathrm{MPa}$, and the time was $12000 \mathrm{~min}(400 \mathrm{cycle} \times 3 \mathrm{~min})$. Approximately $150 \mathrm{~g}$ of torch ginger flowers was loaded into the extractor unit $\left(1 \mathrm{~L}\right.$ capacity). Liquid $\mathrm{CO}_{2}$ was supplied from the tank to the reboiler unit via the V1 valve and was converted into $\mathrm{CO}_{2}$ gas. The $\mathrm{CO}_{2}$ gas was channelled to the condenser unit and condensed into liquid $\mathrm{CO}_{2}$ again. The liquid $\mathrm{CO}_{2}$ evaporated while the torch ginger oil was precipitated at the bottom of the reboiler unit. The yield of oil was expressed as the percentage of oil obtained based on the weight of sample used. The torch ginger oil was sealed in the opaque glass bottles and stored at $8^{\circ} \mathrm{C}$ for further analysis.

2.4. Oil and Microbial Preparations. The oil was dissolved in absolute ethanol at a concentration of $50 \mathrm{mg} / \mathrm{mL}$ and filtered using sterilized $0.2 \mu \mathrm{m}$ syringe filters (Sartorius minisart cellulose, Sartorius Stedim, Göttingen, Germany). The pathogenic bacteria including Salmonella typhimurium ATCC14028, Staphylococcus aureus ATCC6538, and Escherichia coli O157: H7 were obtained from Bioprocessing laboratory, Faculty of Food Science and Technology, Universiti Putra Malaysia (UPM). The pathogenic bacteria were grown in the nutrient broth (MHB) and adjusted to $10^{6} \mathrm{CFU} \cdot \mathrm{mL}^{-1}$ approximately using $0.5 \mathrm{Mc}$ Farland (Becton, New Jersey, USA), and the results were reconfirmed at $600 \mathrm{~nm}$ wavelength using a microplate reader (PowerWave $\times 340$, BioTek Instruments, Inc, Vermont, USA). The standardized activated bacteria suspensions were used for further analyses.

2.5. Antibacterial Assay. The antibacterial activity of torch ginger flower oil was evaluated to determine the potential applications in foods and pharmaceutical industries. Agar 
disc-diffusion assay was carried out to determine the antibacterial activity according to the method described in the Clinical and Laboratory Standard Institute [17]. Briefly, Muller-Hinton Agar (MHA) plates were inoculated with the pathogenic bacteria using a sterile swab. A total of $20 \mu \mathrm{L}$ of the oil extracts $(50 \mathrm{mg} / \mathrm{mL})$ was placed on blank paper discs $(6 \mathrm{~mm})$ and left for drying before the experiment in MHA plates. Absolute ethanol (100\%) served as a negative control, while streptomycin $(25 \mu \mathrm{g} / \mathrm{disc}$, Oxoid, Hampshire, England) served as the positive control. The plates were incubated at $37^{\circ} \mathrm{C}$ for $24 \mathrm{~h}$, and the antibacterial activity was determined by measuring the diameter of the clear zones of inhibition. The assay was done in triplicate for each bacterium.

\subsection{Determination of Minimal Inhibitory Concentration and} Bactericidal Concentration. Minimum inhibitory concentration (MIC) and minimum bactericidal concentration (MBC) were determined following the microdilution broth method [17]. The oil was dissolved in DMSO (10\%), and eight different concentrations were prepared $(80,40,20,10$, $5,2.5,1.25$, and $0.625 \mathrm{mg} / \mathrm{mL}$ ). A total of $180 \mu \mathrm{L}$ of $\mathrm{MHB}$ containing $10^{6} \mathrm{CFU} \cdot \mathrm{mL}^{-1}$ from each pathogenic bacterium was added to the wells, and $20 \mu \mathrm{L}$ of the different oil concentrations was placed in the wells. As the oil $(20 \mu \mathrm{L})$ diluted in the broth $(180 \mu \mathrm{L})$, the final concentrations of the oil in the wells were $8,4,2,1,0.5,0.25,0.125$, and $0.0625 \mathrm{mg} / \mathrm{mL}$. The positive control was streptomycin prepared following the same oil concentrations, and the negative control was $10 \%$ DMSO. The plates were incubated aerobically at $37^{\circ} \mathrm{C}$ for $24 \mathrm{~h}$. The MBC was determined by inoculating $5 \mu \mathrm{L}$ from each well from the 96-well microtitter plate on MHA plates and incubation at $37^{\circ} \mathrm{C}$ for $24 \mathrm{~h}$. The complete growth inhibition represented the MBC. The MIC was determined as the lowest concentration of oil that fully inhibits the bacterial growth. All the experiments were carried out in triplicate.

2.7. GC-MS Metabolic Profiling. The torch ginger flower oil bioactive compounds were identified using QP2010 ultra gas chromatography-mass spectrometer (Shimadzu Corporation, Kyota, Japan) following the method described by Wei et al. [18]. The oil was diluted in the ratio of $1: 10$ with ethanol, and $1 \mu \mathrm{L}$ of the extract was injected into BPX5 capillary column $(30.0 \mathrm{~m} \times 0.25 \mathrm{~mm} \times 0.25 \mu \mathrm{m}$, composed of $5 \%$ phenyl/95\% methylpolysilphenylene/siloxane) (Trajan Scientific, Victoria, Australia). Helium was the carrier gas, and a split ratio of $1: 10$ was used. The oven temperature was kept at $50^{\circ} \mathrm{C}$ and then gradually increased at a rate of $3^{\circ} \mathrm{C} / \mathrm{min}$ to $300^{\circ} \mathrm{C}$ at a linear velocity $32.4 \mathrm{~cm} / \mathrm{sec}$ and held for about $10 \mathrm{~min}$. The temperature at the injection port and detector temperature was $280^{\circ} \mathrm{C}$. Mass spectra were taken at $70 \mathrm{eV}$ (a scan interval of $0.1 \mathrm{~s}$ and scan range from 40 to $700 \mathrm{~m} / \mathrm{z}$ ). The metabolites were identified by matching their mass spectra with those of stored standard compounds in the database using the Shimadzu National Institute of Standards and Technology Mass Spectral database (Shimadzu NIST-MS [18]). The name, molecular weight, and structure of the components of the test extracts were ascertained.

2.8. ${ }^{1} H-N M R$ Metabolic Profiling. The metabolomics profiling was carried out for the torch ginger flower oil to identify the metabolites that demonstrated antibacterial activity. Metabolomics profiling was performed using ${ }^{1} \mathrm{H}$ NMR following the method as described by Mediani et al. [19]. Briefly, $10 \mathrm{mg}$ of the oil sample was mixed with $0.375 \mathrm{~mL}$ of $\mathrm{CH}_{3} \mathrm{OH}-\mathrm{d}_{4}$ and $0.375 \mathrm{~mL}$ of $\mathrm{KH}_{2} \mathrm{PO}_{4}$ buffer in $\mathrm{D}_{2} \mathrm{O}$ ( $\mathrm{pH} 6$ adjusted with $\mathrm{NaOH}$ ) containing $0.1 \%$ TSP. The mixture was subjected to vortex for 1 minute and then then ultrasonicated for 15 minutes at $30^{\circ} \mathrm{C}$. The mixture was centrifuged at $13,000 \mathrm{rpm}$ for 10 minutes, and the supernatant $(600 \mu \mathrm{L})$ was transferred to the NMR tube for ${ }^{1} \mathrm{H}$ NMR analysis using a $500 \mathrm{MHz}$ spectrometer (Varian INOVA model Inc., California, USA). The NMR spectra were analysed using Chenomx NMR Suite version 8.1 (Alberta, Canada) to identify the metabolites and confirmed with Human Metabolome Database (HMDB) [20].

2.9. Statistical Analysis. All experiments for disc diffusion were performed three times with triplication $(n=3 \times 3)$. The results were interpreted as mean \pm standard deviation (SD). Analysis of variance was performed, and the significant differences recorded between mean values were determined by Tukey's pair wise comparison test (level of significance of $P<0.05)$. Statistical analyses were conducted using MINITAB 16 software (Minitab, Inc., State College, Pennsylvania, USA).

\section{Results and Discussion}

The oil of torch ginger flower demonstrated strong antibacterial activity towards the tested pathogenic bacteria in the agar disc-diffusion assay. The diameter of inhibition zones against $S$. aureus and $E$. coli was significantly $(P<0.05)$ higher than that of the positive control, while the positive control exhibited higher clear zone towards S. typhimurium (Table 1). The positive control (streptomycin) inhibition zones ranged from $8.5 \pm 0.4951 \mathrm{~b}$ to $19.5 \pm 0.354 \mathrm{~mm}$ against the tested pathogenic bacteria. However, the 10\% DMSO (negative control) did not show growth inhibition towards the selected bacteria. The oil extracted using subcritical carbon dioxide $\left(\mathrm{CO}_{2}\right)$ demonstrated very strong antibacterial activity against $S$. aureus $(14.5 \pm 2.211 \mathrm{~mm})$. In a previous study, the antibacterial activity of torch ginger flowers oil extracted using dichloromethane against Bacillus cereus was $13 \mathrm{~mm}$ [10]. Moreover, Wijekoon et al. [3] reported that the pathogenic bacteria, namely, $B$. cereus, $B$. subtilis, S. aureus, and Listeria monocytogenes, showed moderated susceptibility to the oil of torch ginger flower that was extracted using solvents. The results of this study demonstrated significantly strong antibacterial activity for torch ginger flower oil extracted using subcritical $\mathrm{CO}_{2}$ technique against the tested pathogenic bacteria.

The antibacterial activity was further evaluated using 96well microtitter plate assay to determine the MIC and MBC. 
TABLe 1: Antibacterial activity of torch ginger (E. elatior Jack) flower oil (50 mg/mL) extracted using subcritical $\mathrm{CO}_{2}$.

\begin{tabular}{lcc}
\hline Microorganism & \multicolumn{1}{c}{ Inhibition zone $(\mathrm{mm})$} & Streptomycin $(25 \mu \mathrm{g} / \mathrm{disc})$ \\
\hline Salmonella typhimurium & EO $(20 \mathrm{mg} / \mathrm{disc})$ & $19.5 \pm 0.354^{a}$ \\
Staphylococcus aureus & $17.5 \pm 0.827^{b}$ & $12.5 \pm 1.424^{b}$ \\
Escherichia coli & $14.5 \pm 2.211^{a}$ & $8.5 \pm 0.4951^{b}$ \\
\hline
\end{tabular}

Values are expressed as mean \pm standard deviation $(n=9)$. Different letters show the significant differences $(P<0.05)$, and same letters show no significant differences in the row.

TABLE 2: The MIC and MBC of torch ginger (E. elatior Jack) flower oil against pathogenic bacteria in comparison to streptomycin.

\begin{tabular}{lcccc}
\hline \multirow{2}{*}{ Microorganism } & EO & \multicolumn{2}{c}{ Streptomycin } \\
& MIC $(\mathrm{mg} / \mathrm{mL})$ & $\mathrm{MBC}(\mathrm{mg} / \mathrm{mL})$ & $\mathrm{MIC}(\mathrm{mg} / \mathrm{mL})$ & 2.5 \\
Salmonella typhimurium & 0.625 & 2.5 & 5 & 5 \\
Staphylococcus aureus & 2.5 & 5 & 5 & 10 \\
Escherichia coli & 2.5 & 10 & 5 & 10 \\
\hline
\end{tabular}

The MIC value of torch ginger flower oil was $0.0625 \mathrm{mg} / \mathrm{mL}$ for S. typhimurium, $0.25 \mathrm{mg} / \mathrm{mL}$ for $S$. aureus, and $0.25 \mathrm{mg} /$ $\mathrm{mL}$ for E. coli. On the other hand, the MBC values were $0.25 \mathrm{mg} / \mathrm{mL}$ for S. typhimurium, $0.5 \mathrm{mg} / \mathrm{mL}$ for $S$. aureus, and $0.25 \mathrm{mg} / \mathrm{mL}$ for $E$. coli (Table 2). In a previous study, Abdelwahab et al. [21] studied the antibacterial activity of torch ginger oil extracted with different solvents. The results showed no growth inhibition against 3 of the tested pathogenic bacteria, while the MIC value for $S$. aureus was $10 \mathrm{mg} /$ $\mathrm{mL}$. However, in this study, the MIC for $S$. aureus was $0.25 \mathrm{mg} / \mathrm{mL}$ which is significantly $(P<0.05)$ low in comparison to the previous studies. In another study, the MIC values for torch ginger aqueous and ethanolic extracts ranged from $37.5-125 \mathrm{mg} / \mathrm{mL}$ to $50-75 \mathrm{mg} / \mathrm{mL}$, respectively, while the MBC values ranged from $50-175 \mathrm{mg} / \mathrm{mL}$ and $50 \mathrm{mg} / \mathrm{mL}$ for aqueous and ethanolic extracts, respectively [22]. The oil extracted by $\mathrm{CO}_{2}$ demonstrated significantly higher antibacterial activity and lower values for the MIC and $\mathrm{MBC}$ towards the pathogenic bacteria in comparison to the solvent extractions reported in the previous studies.

Plant oils contain a great number of secondary metabolites characterized by strong aromas that are used in food and pharmaceutical industries. The oils have a complex composition containing hydrocarbons (terpenes and sesquiterpenes) and oxygenated compounds (acids, acetals, alcohols, aldehydes, esters, ethers, ketones, lactones, oxides, and phenols). In this study, subcritical $\mathrm{CO}_{2}$ extraction yielded in 5.5\% pure yellow oil with a strong antibacterial activity. The strong antibacterial activity of torch ginger flower oil might be due to the high content of fatty alcohol and/or fatty acids [23]. Moreover, major chemical compounds present in torch ginger flower oil such as polyphenols, flavonoids, anthocyanins, and tannins can also possess strong antimicrobial activities against pathogenic bacteria [24]. In this study, the GC-MS profiling led to identify 33 compounds in the oil of torch ginger flower including 15 compounds that are well-known for their antibacterial activity (Table 3 ). The predominant chemical classes of the oil consisted of oxygenated compounds including alcohol (15.53\%) followed by aldehydes $(7.81 \%)$, esters $(5.06 \%)$ acids $(1.27 \%)$, and $(8.23 \%)$ terpene hydrocarbons (monoterpenes and sesquiterpenes). Several previous studies reported the antibacterial activity of fatty acid alcohols against different pathogenic bacteria [24, 38]. Chiang et al. [23] suggested that compounds present at low levels are also having high potential for antibacterial activity that has synergic effects and more than one specific mechanism. However, the strong antibacterial activity of torch ginger flower oil in this study could be due to the extraction method, different sensitivity of the test strain, and the species of the plant. Zoghbi and Andrade [39] identified 15 compounds using GC-MS including 1-dodecanol as major component followed by dodecanal and $\alpha$-pinene. In another study, the oil extracted from different parts of Malaysian torch ginger were analysed by GC-MS, the flowers and rhizomes contained 1-dodecanediol diacetate $(40.4 \%)$ and cyclododecane $(34.5 \%)$, while the leaf contained $\beta$-pinene $(19.7 \%), \beta$-caryophyllene $(15.4 \%)$ and trans- $\beta$-farnesene $(27.1 \%)$, and the stem compounds were 1,1 dodecanediol diacetate $(34.3 \%)$ and trans-5-dodecene $(27.0 \%)$ [40]. The results of this study are in agreement with the previous studies, and major compounds identified are well-known for their antibacterial activity.

The bioactive metabolites were further identified using ${ }^{1} \mathrm{H}$ NMR in combination with the compounds available at Chenomx database. A total of 16 metabolites were identified in the oil of torch ginger extracted by subcritical carbon dioxide including 8 metabolites known for their antimicrobial activity (Table 4). Several acids were identified for the first time in the oil of torch ginger flower such as azelaic acid, butyric acid, citraconic acid, capric acid, caprylic acid, valeric acid, citric acid, syringic acid, chlorogenic acid, and citraconic acid (Figure 1). The results revealed the presence of several saturated fatty acids such as hexacosanoic acid, capric acid, and caprylic acid at high concentrations. Several studies reported the correlation between antibacterial activity and the short fatty acids [43, 47]. NMR analysis is used as the rapid identification method of the main metabolites and their concentrations, especially the metabolites 
TABle 3: GC-MS metabolomics profiling of torch ginger (E. elatior Jack) flower oil.

\begin{tabular}{|c|c|c|c|c|c|}
\hline No. & Compound name & $\mathrm{RT}^{a}$ & Peak area $\%$ & Activity & Reference \\
\hline 1 & Cyclohexane & 2.60 & 0.73 & - & - \\
\hline 2 & Cyclopentanol, 1-methyl- & 4.33 & 0.12 & - & - \\
\hline 3 & $\alpha$-Pinene & 8.16 & 2.23 & Antibacterial & Nissen et al. [25] \\
\hline 4 & cis-pinen-3-ol & 8.95 & 0.16 & - & - \\
\hline 5 & Bornylene & 12.07 & 0.17 & Antibacterial & Goudjil et al. [26] \\
\hline 6 & 2-Nonanone & 15.02 & 0.15 & Antibacterial & $\begin{array}{l}\text { Orlandaand and nascimento, } \\
\text { [27] }\end{array}$ \\
\hline 7 & Nonan-2-ol & 15.49 & 0.33 & - & - \\
\hline 8 & trans-verbenol & 17.81 & 0.31 & Antibacterial & Utegenova et al. [28] \\
\hline 9 & $\alpha$-Terpineol & 20.26 & 0.25 & Antibacterial & Li et al. [29] \\
\hline 10 & Decanal & 20.64 & 0.65 & Antibacterial & Verma et al. [30] \\
\hline 11 & Bicyclo[3.1.1]hept-3-en-2-one, 4,6,6-trimethyl-, (1S) & 20.99 & 0.26 & - & - \\
\hline 12 & 1-Decanol & 23.79 & 1.46 & Antibacterial & Togashi et al. [31] \\
\hline 13 & 2-Undecanone & 24.74 & 1.55 & Antibacterial & $\begin{array}{l}\text { Orlandaand and nascimento, } \\
\text { [27] }\end{array}$ \\
\hline 14 & Methyl nonyl carbinol & 25.11 & 0.37 & - & - \\
\hline 15 & Undecanal & 25.45 & 0.18 & Antibacterial & Kubo et al. [32] \\
\hline 16 & 1-Undecanol & 28.46 & 0.30 & Antibacterial & Togashi et al. [31] \\
\hline 17 & Decanoic acid & 29.36 & 0.30 & Antibacterial & Huang et al. [33] \\
\hline 18 & $( \pm)$ - $\alpha$-Terpinyl acetate & 29.76 & 0.19 & - & - \\
\hline 19 & Dodecanal & 30.30 & 6.50 & - & - \\
\hline 20 & trans-Caryophyllene & 30.52 & 2.09 & - & - \\
\hline 21 & $\alpha$-Humulene & 32.16 & 1.88 & Antibacterial & Azizan et al. [34] \\
\hline 22 & Dodec-(8Z)-en-1-ol & 32.44 & 0.17 & - & - \\
\hline 23 & 1-Dodecanol & 33.46 & 11.44 & - & - \\
\hline 24 & $\begin{array}{l}\text { Bicyclo[3.1.1]hept-2-ene, 2,6-dimethyl-6-(4-methyl-3- } \\
\text { pentenyl) }\end{array}$ & 33.60 & 0.87 & - & - \\
\hline 25 & 2-Tridecanone & 33.93 & 1.09 & - & - \\
\hline 26 & $\alpha$-Bisabolol & 34.31 & 0.04 & Antibacterial & de sousa oliveira et al. [35] \\
\hline 27 & Mentha-1(7),8-dien-2-ol, cis-para & 34.56 & 0.23 & - & - \\
\hline 28 & Methyl dodecanoate & 34.96 & 0.84 & - & - \\
\hline 29 & 1,6,10-Dodecatrien-3-ol, 3,7,11-trimethyl & 36.52 & 0.35 & - & - \\
\hline 30 & Dodecanal $<$ dimethyl- $>$ acetal & 36.89 & 0.48 & - & - \\
\hline 31 & Oleic acid & 37.10 & 0.09 & Antibacterial & Dilika et al. [36] \\
\hline 32 & Lauryl acetate & 38.49 & 4.03 & - & - \\
\hline 33 & Lauric acid & 38.77 & 0.88 & Antibacterial & Nakatsuji et al. [37] \\
\hline
\end{tabular}

${ }^{a} \mathrm{RT}$, retention time (min).

TABLE 4: Chemical shifts and concentrations of the bioactive metabolites identified in the oil of torch ginger flower.

\begin{tabular}{|c|c|c|c|c|c|}
\hline No. & Metabolites & Chemical shift & $\begin{array}{c}\text { Concentration } \\
\mathrm{mM}\end{array}$ & Activity & Reference \\
\hline 1 & Hexacosanoic acid & $\delta 0.87(\mathrm{t})$ & 0.3351 & Antimicrobial & Singh and Singh, [41] \\
\hline 2 & Methylmalonic acid & $\delta 1.23(\mathrm{~d})$ & 1.0311 & - & - \\
\hline 3 & Azelaic acid & $\delta 1.54(\mathrm{~m})$ & 0.1341 & Antimicrobial & Leeming et al. [42] \\
\hline 4 & Butyric acid & $\delta 1.55(\mathrm{tq})$ & 0.316 & Antibacterial & Fernández-Rubio et al. [43] \\
\hline 5 & Citraconic acid & $\delta 1.93(\mathrm{~s}), \delta 5.598(\mathrm{~d})$ & 0.0925 & - & - \\
\hline 6 & Capric acid & $\begin{array}{c}\delta 2.16 \text { (br s), } \delta 1.53 \text { (br s), } \delta 1.27 \text { (br s), } \delta \\
0.85 \text { (br s) }\end{array}$ & 0.3272 & Antimicrobial & Bergsson et al. [44] \\
\hline 7 & Caprylic acid & $\delta 2.16(\mathrm{t}), \delta 1.53(\mathrm{~m}), \delta 1.27(\mathrm{~d}), \delta 0.85(\mathrm{~m})$ & 0.2272 & Antimicrobial & Nair et al. [45] \\
\hline 8 & Valeric acid & $\delta 2.19(\mathrm{t})$ & 0.3137 & Antimicrobial & Sunkara et al. [46] \\
\hline 9 & Citric acid & $\delta 2.66(\mathrm{~d}), \delta 2.52(\mathrm{~d})$ & 0.0299 & Antimicrobial & Allende et al. [47] \\
\hline 10 & Ethanolamine & $\delta 3.13(\mathrm{~d}, J=19.8 \mathrm{~Hz})$ & 0.0222 & - & - \\
\hline 11 & $\begin{array}{l}\text { Trimethylamine } \mathrm{N}- \\
\text { oxide }\end{array}$ & $\delta 3.25(\mathrm{~s})$ & 0.157 & - & - \\
\hline 12 & 1,3-Dimethyluric acid & $\delta 3.29(\mathrm{~s})$ & 0.4813 & - & - \\
\hline 13 & 1,3-Dimethyluric & $\delta 3.428(\mathrm{~s}), \delta 3.298(\mathrm{~s})$ & 0.0257 & - & - \\
\hline 14 & Sarcosine & $\delta 3.6(\mathrm{~s})$ & 0.0536 & - & - \\
\hline 15 & Syringic acid & $\delta 3.84(\mathrm{~s})$ & 0.0126 & - & - \\
\hline 16 & Chlorogenic acid & $\delta 5.33(\mathrm{~m})$ & 0.1234 & Antimicrobial & Tajik et al. [48] \\
\hline
\end{tabular}




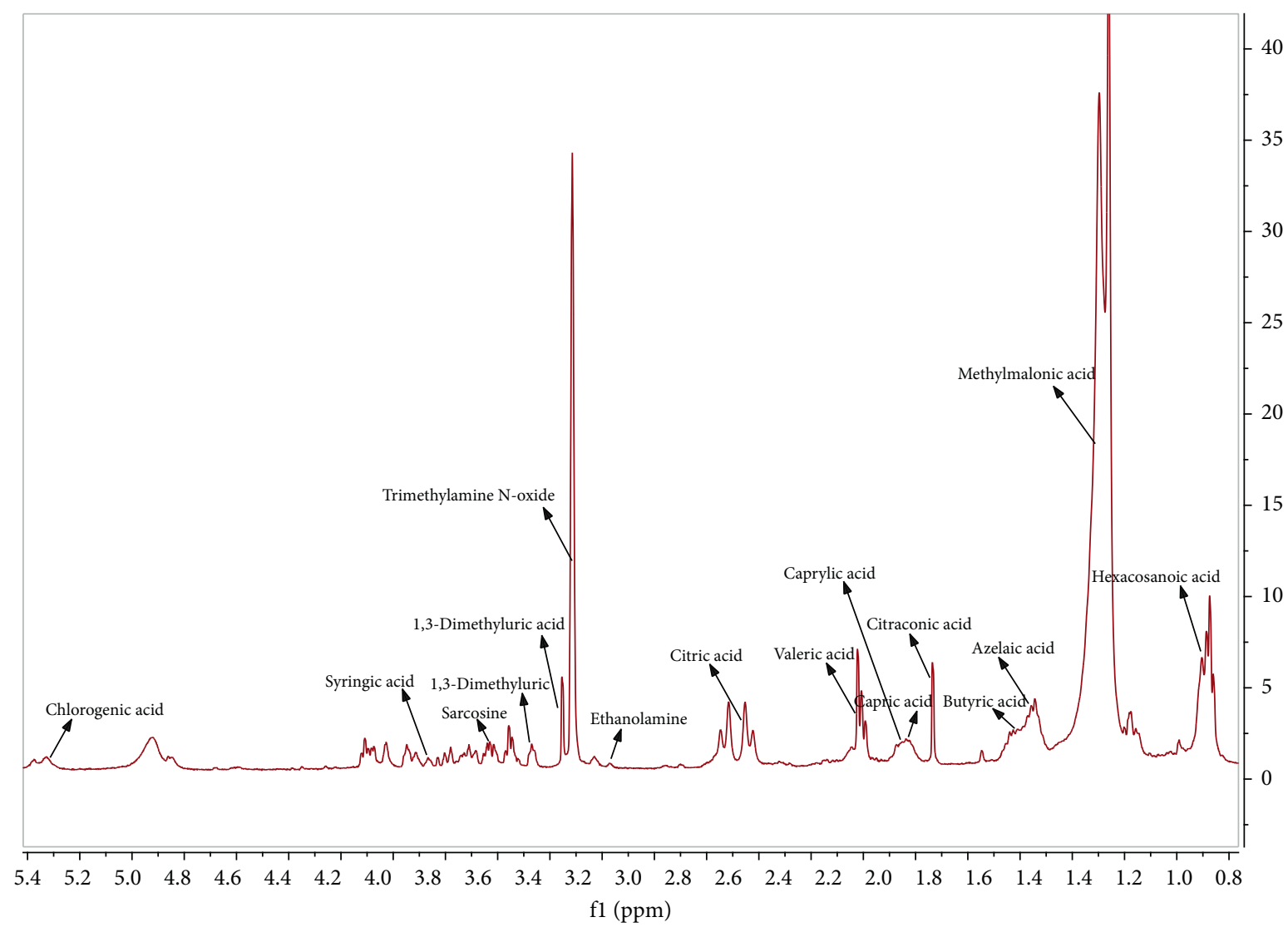

FIGURE 1: ${ }^{1} \mathrm{H}-\mathrm{NMR}$ representative spectra of the identified metabolites of the oil extracted from torch ginger flower by the subcritical carbon dioxide method.

that demonstrated strong antimicrobial activity. Anderson et al. [49] identified several compounds of 6 oil samples using the combination of ${ }^{1} \mathrm{H}-\mathrm{NMR}$ and the principle component analysis (PCA). In another study, NMR analysis was used to discriminate several oils including olive, hazelnut, and sunflower [50]. Moreover, interesting results were observed for the chilli, black pepper, and ginger oils extracted using subcritical $\mathrm{CO}_{2}$ and analysed by NMR, and the results demonstrated higher concentration of the bioactive compounds in comparison to conventional extraction by organic solvents [51].

Torch ginger flower oil was subjected to storage to determine the stability of the antibacterial activity and the potential applications in pharmaceutical and food industries. In a previous study, oil was applied as natural preservative to extend the shelf life and prevented spoilage [52]. In this study, the extracted oil exhibited strong antibacterial activity against the tested pathogenic bacteria after being stored for 12 months at $8^{\circ} \mathrm{C}$. Several previous studies recommended storing the oils at $-20^{\circ} \mathrm{C}$ to reduce oxidation of the oil and maintain the biological activity $[53,54]$. However, the results of this study demonstrated minimal effects of the storage at $8^{\circ} \mathrm{C}$ for 12 months on the stability of the antimicrobial activity of the oil extracted using subcritical $\mathrm{CO}_{2}$. Scollard et al. [55] reported similar results for the oils extracted from thyme, oregano, and rosemary that maintained the antibacterial activity against $L$. monocytogenes during the storage at $4^{\circ} \mathrm{C}-8^{\circ} \mathrm{C}$. The results indicated that the extraction of the oil using subcritical $\mathrm{CO}_{2}$ was able to maintain the strong antimicrobial activity.

\section{Conclusion}

Subcritical carbon dioxide $\left(\mathrm{CO}_{2}\right)$ extraction was applied to extract oil from torch ginger flowers with minimum effect on the antibacterial activity. $\mathrm{CO}_{2}$ extraction at low temperature prevented thermal degradation of the bioactive compounds. The oil of torch ginger flower contained bioactive compounds such as 1-dodecanol, saturated fatty acids, and organic acids that demonstrated a strong antimicrobial activity. The combination of GCMS and NMR-based metabolomics profiling was used to identify the bioactive compounds in the oil. The oil of torch ginger flower extracted with subcritical $\mathrm{CO}_{2}$ has a high potential for pharmaceutical and food applications as natural antibacterial agents. The antibacterial activity of the extracted oil was very stable after the storage for 12 months at $8^{\circ} \mathrm{C}$. Further study is recommended to optimize the extraction conditions and enhance the yield of the extracted oil.

\section{Data Availability}

All data used to support the findings of this study are included within the article. 


\section{Conflicts of Interest}

The authors declare that there are no conflicts of interest.

\section{Acknowledgments}

This work was supported by the Universiti Putra Malaysia (grant number UPM/700-2/1/GPB/2017/9570400). The authors would like to thank the technical staff in the Supercritical Fluid Centre at the Faculty of Food Science and Technology.

\section{References}

[1] N.-G. Tao and Y.-J. Liu, "Chemical composition and antimicrobial activity of the essential oil from the peel of shatian pummelo (citrus Grandis Osbeck)," International Journal of Food Properties, vol. 15, no. 3, pp. 709-716, 2012.

[2] E. W. C. Chan, Y. Y. Lim, and S. K. Wong, "Phytochemistry and pharmacological properties of Etlingera elatior: a review," Pharmacognosy Journal, vol. 3, no. 22, pp. 6-10, 2011.

[3] M. M. J. O. Wijekoon, R. Bhat, A. A. Karim, and A. Fazilah, "Chemical composition and antimicrobial activity of essential oil and solvent extracts of torch ginger inflorescence (Etlingera elatior Jack.)," International Journal of Food Properties, vol. 16, no. 6, pp. 1200-1210, 2013.

[4] L. Y. W. Chua, C. H. Chong, B. L. Chua, and A. Figiel, "Influence of drying methods on the antibacterial, antioxidant and essential oil volatile composition of herbs: a review," Food and Bioprocess Technology, vol. 12, no. 3, pp. 450-476, 2019.

[5] N. Foster, R. Mammucari, F. Dehghani et al., "Processing pharmaceutical compounds using dense gas technology," Industrial \& Engineering Chemistry Research, vol. 42, no. 25, pp. 6476-6493, 2003.

[6] C. Grosso, P. Valentão, F. Ferreres, and P. Andrade, "Alternative and efficient extraction methods for marine-derived compounds," Marine Drugs, vol. 13, no. 5, pp. 3182-3230, 2015.

[7] M. Khajeh, Y. Yamini, F. Sefidkon, and N. Bahramifar, "Comparison of essential oil composition of Carum copticum obtained by supercritical carbon dioxide extraction and hydrodistillation methods," Food Chemistry, vol. 86, no. 4, pp. 587-591, 2004.

[8] S. Hamdan, H. G. Daood, M. Toth-Markus, and V. Illés, "Extraction of cardamom oil by supercritical carbon dioxide and sub-critical propane," The Journal of Supercritical Fluids, vol. 44, no. 1, pp. 25-30, 2008.

[9] A. H. A. Abdelmageed, Q. Z. Faridah, and M. Yaacob, "The influence of organ and post-harvest drying period on yield and chemical composition of the essential oils of Etlingera elatior (Zingiberaceae)," Journal of Medicinal Plants Research, vol. 5, no. 15, pp. 3432-3439, 2011.

[10] D. Susanti, N. A. Awang, H. Qaralleh, H. I. Sheikh Mohamed, and N. Attoumani, "Antimicrobial activity and chemical composition of essential oil of Malaysian Etlingera elatior (jack) R.M. Smith flowers," Journal of Essential Oil Bearing Plants, vol. 16, no. 2, pp. 294-299, 2013.

[11] B. Mahdavi, W. A. Yaacob, and L. B. Din, "Chemical composition, antioxidant, and antibacterial activity of essential oils from Etlingera sayapensis A.D. Poulsen \& Ibrahim," Asian Pacific Journal of Tropical Medicine, vol. 10, no. 8, pp. 819826, 2017.

[12] Y. Sultanbawa, "Essential oils in food applications: Australian aspects," in Essential Oils in Food Preservation, Flavor and
Safety, pp. 155-160, Academic Press, Cambridge, MA, USA, 2016.

[13] S. Harpaz, L. Glatman, V. Drabkin, and A. Gelman, "Effects of herbal essential oils used to extend the shelf life of freshwaterreared Asian sea bass fish (Lates calcarifer)," Journal of Food Protection, vol. 66, no. 3, pp. 410-417, 2003.

[14] N. Harbourne, E. Marete, J. C. Jacquier, and D. O’Riordan, "Stability of phytochemicals as sources of anti-inflammatory nutraceuticals in beverages-a review," Food Research International, vol. 50, no. 2, pp. 480-486, 2013.

[15] H. C. Voon, R. Bhat, and G. Rusul, "Flower extracts and their essential oils as potential antimicrobial agents for food uses and pharmaceutical applications," Comprehensive Reviews in Food Science and Food Safety, vol. 11, no. 1, pp. 34-55, 2012.

[16] K. Taraj, "Extraction of chamomile essential oil by subcritical $\mathrm{CO}_{2}$ and its analysis by UV-VIS spectrophotometer," Asian Journal of Chemistry, vol. 25, no. 13, 2013.

[17] J. C. Lopez-Romero, H. González-Ríos, A. Borges, and M. Simões, "Antibacterial effects and mode of action of selected essential oils components against Escherichia coli and Staphylococcus aureus," Evidence-Based Complementary and Alternative Medicine, vol. 2015, Article ID 795435, 9 pages, 2015.

[18] L. S. Wei, W. Wee, J. Y. F. Siong, and D. F. Syamsumir, "Characterization of anticancer, antimicrobial, antioxidant properties and chemical compositions of Peperomia pellucida leaf extract," Acta Medica Iranica, vol. 49, no. 10, pp. 670-674, 2011.

[19] A. Mediani, F. Abas, A. Khatib et al., "1H-NMR-based metabolomics approach to understanding the drying effects on the phytochemicals in Cosmos caudatus," Food Research International, vol. 49, no. 2, pp. 763-770, 2012.

[20] D. S. Wishart, Y. D. Feunang, A. C. Guo et al., "DrugBank 5.0: a major update to the DrugBank database for 2018," Nucleic Acids Research, vol. 46, no. D1, pp. D1074-D1082, 2018.

[21] S. I. Abdelwahab, F. Q. Zaman, A. A. Mariod, M. Yaacob, A. H. Ahmed Abdelmageed, and S. Khamis, "Chemical composition, antioxidant and antibacterial properties of the essential oils of Etlingera elatior and Cinnamomum pubescens Kochummen," Journal of the Science of Food and Agriculture, vol. 90, no. 15, pp. 2682-2688, 2010.

[22] N. Aziman, N. Abdullah, Z. M. Noor, W. S. S. W. Kamarudin, and K. S. Zulkifli, "Phytochemical profiles and antimicrobial activity of aromatic Malaysian herb extracts against foodborne pathogenic and food spoilage microorganisms," Journal of Food Science, vol. 79, no. 4, pp. M583-M592, 2014.

[23] E. C. W. Chiang, L. Y. Yan, and N. A. M. Ali, "Composition and antibacterial activity of essential oils from leaves of Etlingera species (Zingiberaceae)," International Journal for the Advancement of Science and Arts, vol. 1, p. 1, 2010.

[24] S. Burt, "Essential oils: their antibacterial properties and potential applications in foods-a review," International Journal of Food Microbiology, vol. 94, no. 3, pp. 223-253, 2004.

[25] L. Nissen, A. Zatta, I. Stefanini et al., "Characterization and antimicrobial activity of essential oils of industrial hemp varieties (Cannabis sativa L.)," Fitoterapia, vol. 81, no. 5, pp. 413-419, 2010.

[26] M. B. Gouldjil, S. Ladjel, S. E. Bencheikh, S. Zighmi, and D. Hamada, "Study of the chemical composition, antibacterial and antioxidant activities of the essential oil extracted from the leaves of Algerian Laurus nobilis Lauraceae," Journal of Chemical and Pharmaceutical Research, vol. 7, no. 1, pp. 379-385, 2015. 
[27] J. F. Orlanda and A. R. Nascimento, "Chemical composition and antibacterial activity of Ruta graveolens L.(Rutaceae) volatile oils, from São Luís, Maranhão, Brazil," South African Journal of Botany, vol. 99, pp. 103-106, 2015.

[28] G. Utegenova, K. Pallister, S. Kushnarenko et al., "Chemical composition and antibacterial activity of essential oils from Ferula L. species against methicillin-resistant Staphylococcus aureus," Molecules, vol. 23, no. 7, p. 1679, 2018.

[29] L. Li, C. Shi, Z. Yin et al., "Antibacterial activity of $\alpha$-terpineol may induce morphostructural alterations in Escherichia coli," Brazilian Journal of Microbiology, vol. 45, no. 4, pp. 14091413, 2014.

[30] R. S. Quinn, N. Joshi, R. C. Padalia et al., "Chemical composition and allelopathic, antibacterial, antifungal, and antiacetylcholinesterase activity of fish-mint (Houttuynia cordata Thunb.) from India," Chemistry \& Biodiversity, vol. 14, no. 10, Article ID e1700189, 2017.

[31] N. Togashi, A. Shiraishi, M. Nishizaka et al., "Antibacterial activity of long-chain fatty alcohols against Staphylococcus aureus," Molecules, vol. 12, no. 2, pp. 139-148, 2007.

[32] I. Kubo, K.-i. Fujita, A. Kubo, K.-i. Nihei, and T. Ogura, "Antibacterial activity of coriander volatile compounds against Salmonella choleraesuis," Journal of Agricultural and Food Chemistry, vol. 52, no. 11, pp. 3329-3332, 2004.

[33] W.-C. Huang, T.-H. Tsai, L.-T. Chuang, Y.-Y. Li, C. C. Zouboulis, and P.-J. Tsai, "Anti-bacterial and anti-inflammatory properties of capric acid against Propionibacterium acnes: a comparative study with lauric acid," Journal of Dermatological Science, vol. 73, no. 3, pp. 232-240, 2014.

[34] N. Azizan, S. Mohd Said, Z. Zainal Abidin, and I. Jantan, "Composition and antibacterial activity of the essential oils of Orthosiphon stamineus benth and Ficus deltoidea Jack against pathogenic oral bacteria," Molecules, vol. 22, no. 12, p. 2135 , 2017.

[35] F. d. S. Oliveira, T. S. d. Freitas, R. P. d. Cruz et al., "Evaluation of the antibacterial and modulatory potential of $\alpha$-bisabolol, $\beta$-cyclodextrin and $\alpha$-bisabolol/ $\beta$-cyclodextrin complex," Biomedicine \& Pharmacotherapy, vol. 92, pp. 1111-1118, 2017.

[36] F. Dilika, P. D. Bremner, and J. J. M. Meyer, "Antibacterial activity of linoleic and oleic acids isolated from Helichrysum pedunculatum: a plant used during circumcision rites," Fitoterapia, vol. 71, no. 4, pp. 450-452, 2000.

[37] T. Nakatsuji, M. C. Kao, J.-Y. Fang et al., "Antimicrobial property of lauric acid against Propionibacterium acnes: its therapeutic potential for inflammatory acne vulgaris," Journal of Investigative Dermatology, vol. 129, no. 10, pp. 2480-2488, 2009.

[38] F. Şahin, I. Karaman, M. Güllüce, et al., "Evaluation of antimicrobial activities of Satureja hortensis L," Journal of Ethnopharmacology, vol. 87, no. 1, pp. 61-65, 2003.

[39] M. d. G. B. Zoghbi and E. H. A. Andrade, "Volatiles of the Etlingera elatior (jack) R. M. Sm. and Zingiber spectabile Griff.: two zingiberaceae cultivated in the amazon," Journal of Essential Oil Research, vol. 17, no. 2, pp. 209-211, 2005.

[40] F. M. Jaafar, C. P. Osman, N. H. Ismail, and K. Awang, "Analysis of essential oils of leaves, stems, flowers and rhizomes of Etlingera elatior (Jack) RM Smith," The Malaysian Journal of Analytical Sciences, vol. 11, no. 1, pp. 269-273, 2007.

[41] B. Singh and S. Singh, "Antimicrobial activity of terpenoids fromTrichodesma amplexicaule Roth," Phytotherapy Research, vol. 17, no. 7, pp. 814-816, 2003.

[42] J. P. Leeming, K. T. Holland, and R. A. Bojar, "The in vitro antimicrobial effect of azelaic acid," British Journal of Dermatology, vol. 115, no. 5, pp. 551-556, 1986.
[43] C. Fernández-Rubio, C. Ordóñez, J. Abad-González et al., "Butyric acid-based feed additives help protect broiler chickens from Salmonella Enteritidis infection," Poultry Science, vol. 88, no. 5, pp. 943-948, 2009.

[44] G. Bergsson, J. Arnfinnsson, O. Steingrímsson, and $\mathrm{H}$. Thormar, "In vitro killing of Candida albicans by fatty acids and monoglycerides," Antimicrobial Agents and Chemotherapy, vol. 45, no. 11, pp. 3209-3212, 2001.

[45] M. K. M. Nair, J. Joy, P. Vasudevan, L. Hinckley, T. A. Hoagland, and K. S. Venkitanarayanan, "Antibacterial effect of caprylic acid and monocaprylin on major bacterial mastitis pathogens," Journal of Dairy Science, vol. 88, no. 10, pp. 3488-3495, 2005.

[46] L. T. Sunkara, W. Jiang, and G. Zhang, "Modulation of antimicrobial host defense peptide gene expression by free fatty acids," PLoS One, vol. 7, no. 11, Article ID e49558, 2012.

[47] A. Allende, J. McEvoy, Y. Tao, and Y. Luo, "Antimicrobial effect of acidified sodium chlorite, sodium chlorite, sodium hypochlorite, and citric acid on Escherichia coli O157:H7 and natural microflora of fresh-cut cilantro," Food Control, vol. 20, no. 3, pp. 230-234, 2009.

[48] N. Tajik, M. Tajik, I. Mack, and P. Enck, “The potential effects of chlorogenic acid, the main phenolic components in coffee, on health: a comprehensive review of the literature," European Journal of Nutrition, vol. 56, no. 7, pp. 2215-2244, 2017.

[49] S. L. Anderson, D. Rovnyak, and T. G. Strein, "Identification of edible oils by principal component analysis of $1 \mathrm{H}$ NMR spectra," Journal of Chemical Education, vol. 94, no. 9, pp. 1377-1382, 2017.

[50] C. Fauhl, F. Reniero, and C. Guillou, "1H NMR as a tool for the analysis of mixtures of virgin olive oil with oils of different botanical origin," Magnetic Resonance in Chemistry, vol. 38, no. 6, pp. 436-443, 2000.

[51] O. J. Catchpole, J. B. Grey, N. B. Perry, E. J. Burgess, W. A. Redmond, and N. G. Porter, "Extraction of chili, black pepper, and ginger with near-critical $\mathrm{CO}_{2}$, propane, and dimethyl ether: analysis of the extracts by quantitative nuclear magnetic resonance," Journal of Agricultural and Food Chemistry, vol. 51, no. 17, pp. 4853-4860, 2003.

[52] A. Hassoun and Ö. Emir Çoban, "Essential oils for antimicrobial and antioxidant applications in fish and other seafood products," Trends in Food Science \& Technology, vol. 68, pp. 26-36, 2017.

[53] A. S. Jesus, A. F. Blank, M. F. Alves, M. F. Arrigoni-Blank, R. N. Lima, and P. B. Alves, "Influence of storage time and temperature on the chemical composition of the essential oil of Hyptis pectinata L. Poit," Revista Brasileira de Plantas Medicinais, vol. 18, no. 1_suppl_1, pp. 336-340, 2016.

[54] M. Mohamadi, A. Mostafavi, and T. Shamspur, "Effect of storage on essential oil content and composition of Rosa damascena Mill. Petals under different conditions," Journal of Essential Oil Bearing Plants, vol. 14, no. 4, pp. 430-441, 2011.

[55] J. Scollard, G. A. Francis, and D. O'beirne, "Effects of essential oil treatment, gas atmosphere, and storage temperature on Listeria monocytogenes in a model vegetable system," Journal of Food Protection, vol. 72, no. 6, pp. 1209-1215, 2009. 